\title{
Development of Graphical Computer Software for the Design of Composite Steel I-Girder Bridges per the Canadian Highway Bridge Design Code
}

\author{
Ahmed Diab $^{1}$, Khaled Sennah ${ }^{1}$ \\ ${ }^{1}$ Ryerson University \\ 350 Victoria St, Toronto, Ontario, Canada \\ adiab@ryerson.ca; ksennah@ryerson.ca
}

\begin{abstract}
With increased prices of steel, bridge owners and design engineers may have become reluctant to using steel in bridge superstructure, as it may be cost prohibitive. During the preparation of bid documents, bridge design engineers select a bridge geometry which complies with functional requirements of the highway. While preliminary section sizes for precast concrete girders are available in the literature for use in the bidding process, no similar data is available for structural steel girders. So, the objective of this research is to establish ready-to-use design tables of steel I-girder bridges based on simplified analysis and design procedure specified in the Canadian Highway Bridge Design Code. The bridge analysis and design procedure were performed through a developed graphical computer software. The optimum steel girder section sizes were reached through iterative process to satisfy the ultimate, serviceability and fatigue limit state design procedure. The computer software discussed in this paper obtains input from the user, namely: (a) bridge dimensions, (b) truck type, and (c) design limit states required to be performed. The software is designed to generate accurate data for concrete slab-over-steel I-girder bridges ranging from 1 to 4 spans with span lengths ranging between 12 and $48 \mathrm{~m}$. In terms of design trucks, the software considers (i) CL-625 - Canadian truck, (ii) CL625-ONT - Ontario truck, and (iii) CL-800 - Alberta truck. Results from the software for different bridge configurations were presented in the form of minimum required top and bottom flange areas and web thickness of the steel girders, and thus the structural steel content, to accelerate the process of bidding on bridge projects.
\end{abstract}

Keywords: Computer Programming, Finite-Element Modelling, Bridge Analysis, Load Calculation, Bridge Design, IGirder Bridge, CHBDC, Project Bid Process, Steel Construction.

\section{Introduction}

During the preparation of bid documents, bridge design engineers select a bridge geometry which complies with functional requirements of the highway. Moreover, bidders have to select between steel and concrete superstructure. However, due to the availability of information regarding precast concrete girders in ready-made manuals, such as the PCI Design Handbook, combined with the shortage of time, bidders usually decide to select a concrete superstructure [1]. On the other hand, the literature review showed that the Canadian steel industry does not provide any means to the project bidders to choose a proper section sizing without spending too much time going through the full design procedure specified in the Canadian Highway Bridge Design Code, CHBDC [2]. Also, Ontario Ministry of Transportation (MTO) published a Manual for Standard Short Span Steel Bridges in 1997 that provides engineers with proper W- and WWF-section sizes for steel girders in simple span bridges of spans ranging from 12 to $40 \mathrm{~m}$ and bridge widths of 8.6 and $12.96 \mathrm{~m}$ [3]. Also, MTO published CANBAS software that was used by engineers to quickly analyse and design different bridge dimensions including steel girders [4]. However, the MTO manual and the software were recently considered outdated since they were based on the then Ontario Highway Bridge Design Code [5]. The software presented in this paper aims at providing a quick and optimized design method, based on the 2019 CHBDC, for bidders who would like to choose steel I-girder sections for their proposed bridge superstructure in order to accelerate their bidding process.

\section{Methodology}

To develop a graphical computer software for the design of composite steel I-girder bridges per the Canadian Highway Bridge Design Code, flowcharts for each limit state design was first established. In order to be able to study the 
relationships between all design parameters that affect the selection of a steel girder section, a VB.Net software was developed to perform the following functions: 1) calculate the applied dead load and live load on the bridge girder; 2) obtain applied moment, shear and live load deflection at ultimate, serviceability and fatigue limit states (ULS, SLS and FLS); 3) assess the girder section for limiting permanent (plastic) deflection due to sequence of flexural stresses in unshored construction (SLS1); 4) assess girder flexural strength due to applied moment before concrete hardening (ULS); 5) assess girder cross-section for superstructure vibration (SLS2); 6) assess girder section for resistance against applied factored shear, moment and their combined effect (ULS); 7) asses girder section for flexural resistance for fatigue limit state (FLS); and 8) provide optimized I-girder design based on iterative analysis of flange and web dimensions.

\subsection{Load Calculation}

The developed software considers three truck loading configurations, namely: CL-625 truck loading this is used in design of bridges all over Canada except in Alberta and Ontario, CL625-ONT truck loading used in Ontario, and CL-800 truck loading used in Alberta. Rather than extending the software to conduct finite-element analysis of simply-supported and continuous girders to obtain girder moment, shear and deflection due to traffic loading (i.e. truck loading and lane loading), Diab and Sennah [6] used the Influence Line approach and SAP2000 software to develop expressions for these quantities for each truck type. These empirical expressions for moment $\left(\mathrm{M}_{\mathrm{T}}\right)$, shear force $\left(\mathrm{V}_{\mathrm{T}}\right)$ and deflection $\left(\Delta_{\mathrm{T}}\right)$ were included in the developed software as input data as a function of bridge span and continuity. These expressions cover bridge spans from 12 to $48 \mathrm{~m}$ and number of bridge continuous spans from 2 to 4 in addition to the simply-span bridge configuration.

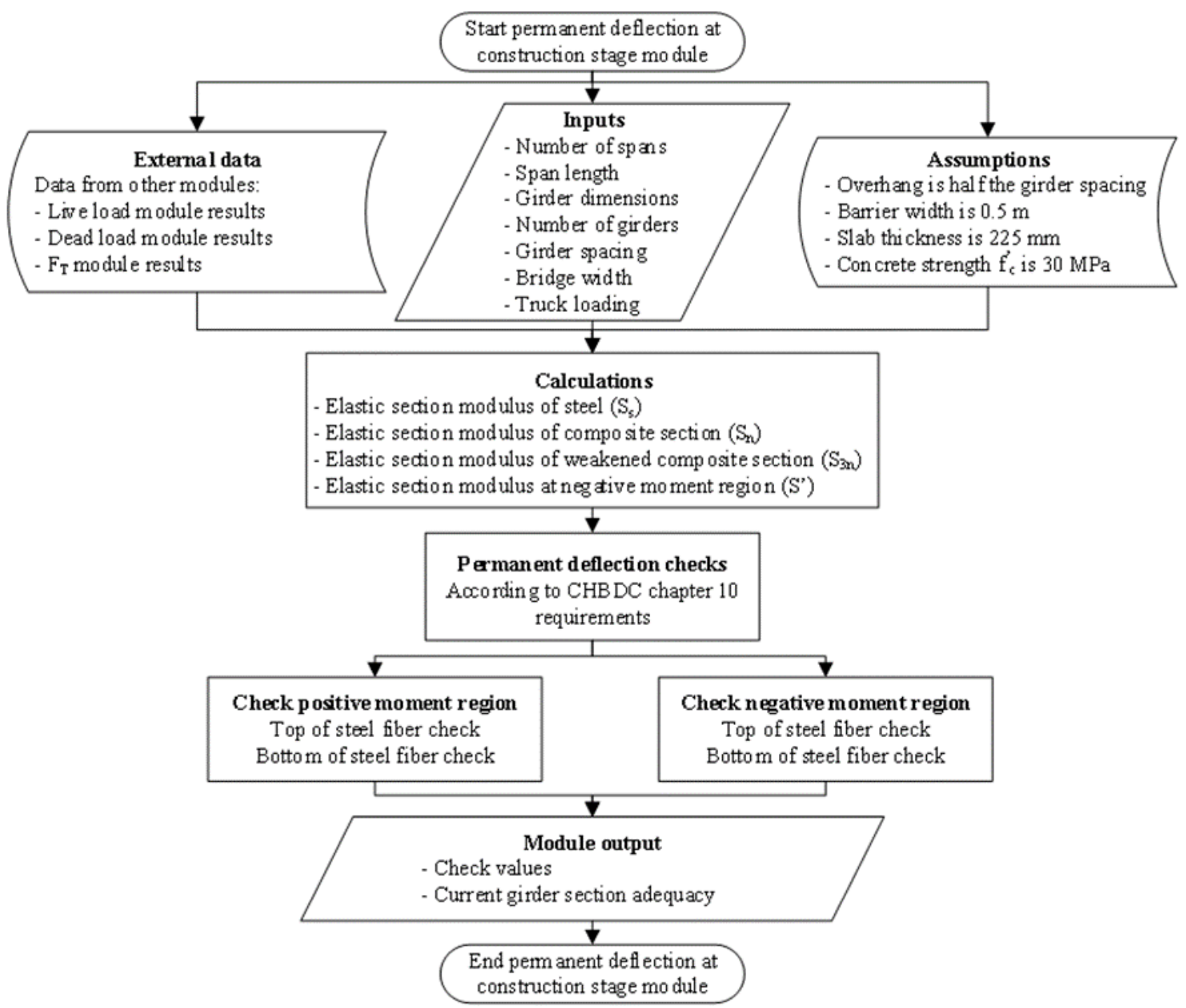

Figure 1: Flowchart showing the algorithm for to check of permanent deflection due to sequence of unshored construction 


\subsection{Algorithm for Check of Permanent Deflection due to Sequence of Unshored Construction}

An algorithm was written to check for permanent deflection due to sequence of unshored construction per CHBDC provisions at serviceability limit state (load combination 1, SLS1). Figure 1 outlines the detailed procedure and assumptions for that portion of the software. The algorithm ensure that stresses due to accumulated dead and live loads due to sequence of construction and while the bridge is on service in normal traffic conditions do not exceed the limiting steel stress at the end of the elastic range.

\subsection{Algorithm for Superstructure Vibration Check}

An algorithm was written to check for live load deflection per CHBDC provisions at serviceability limit state (load combination 2, SLS2). The check is meant to ensure that the live load deflection is less than or equal the live load deflection limit with the assumption that the steel girder will be cambered by the amount of dead load deflection. Figure 2 outlines the algorithm, assumptions and output for that portion of the design process.

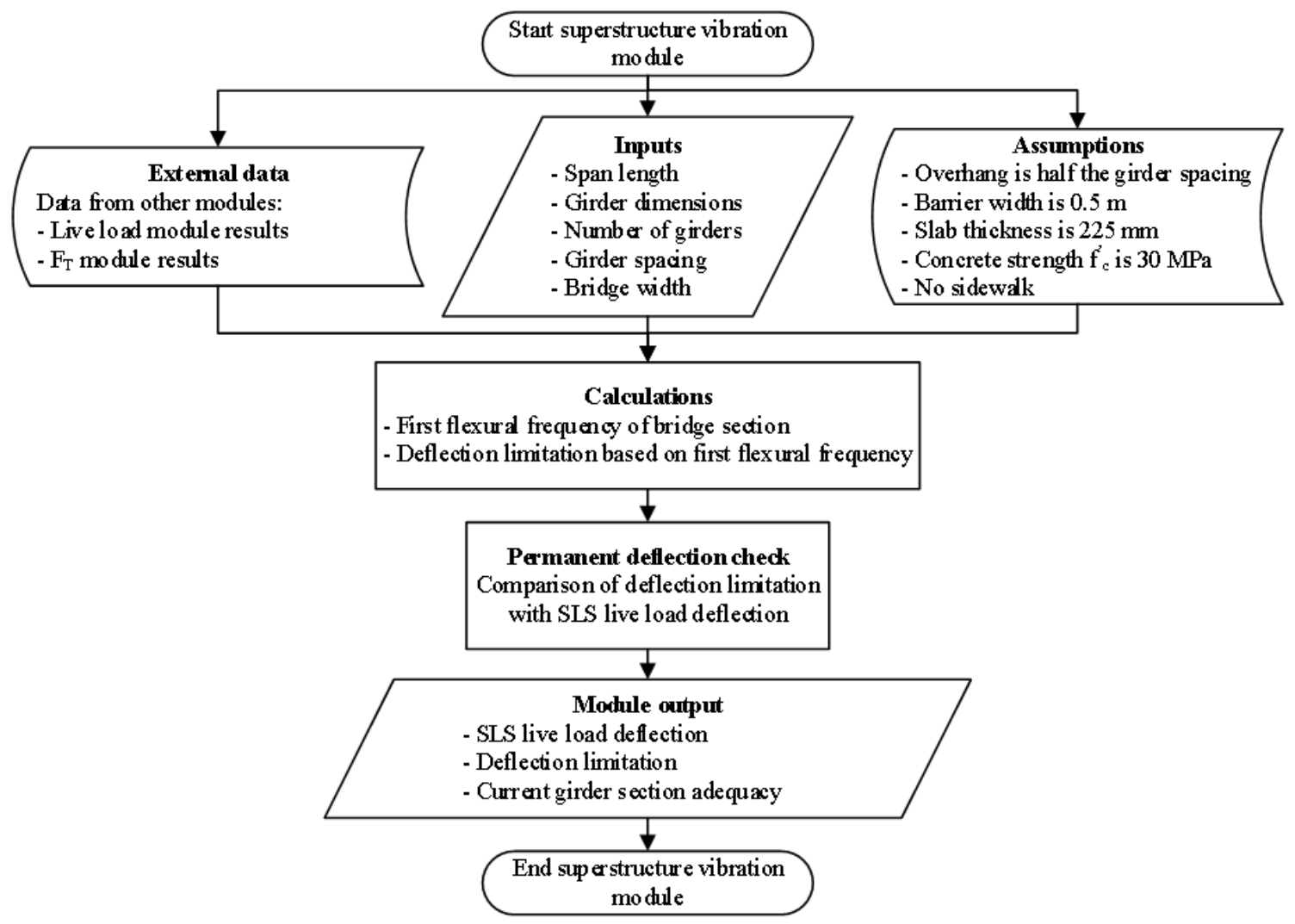

Figure 2: Flowchart showing the algorithm of the superstructure vibration module

\subsection{Algorithm for the Steel Girder Ultimate Strength Check at Construction Stage}

An algorithm was written to check the ultimate flexural resistance of the steel girder when subjected to the factored dead loads after casting the concrete deck slab and before concrete hardening. In this limit state, the steel girder is examined for failure due to lateral torsional buckling failure and failure due section full plasticity or yielding. The selected girder should be able to withstand such loads prior to slab hardening. Figure 3 describes that portion of the software.

\subsection{Algorithm for Flexural Strength of the Composite Girders}

This module encompasses the shear force and bending moment checks at ultimate lime state (ULS). It obtains input regarding the imposed factored applied loading, girder dimensions and material properties. The software then proceeds to find the resisting moment and shear of the composite I-girder section and compare them to the applied factored values. The 
results are displayed in the form of girder adequacy against factored design values at the maximum positive and negative moment locations as well as at the supports for factored shear forces. The algorithm for this portion is shown in Figure 4.

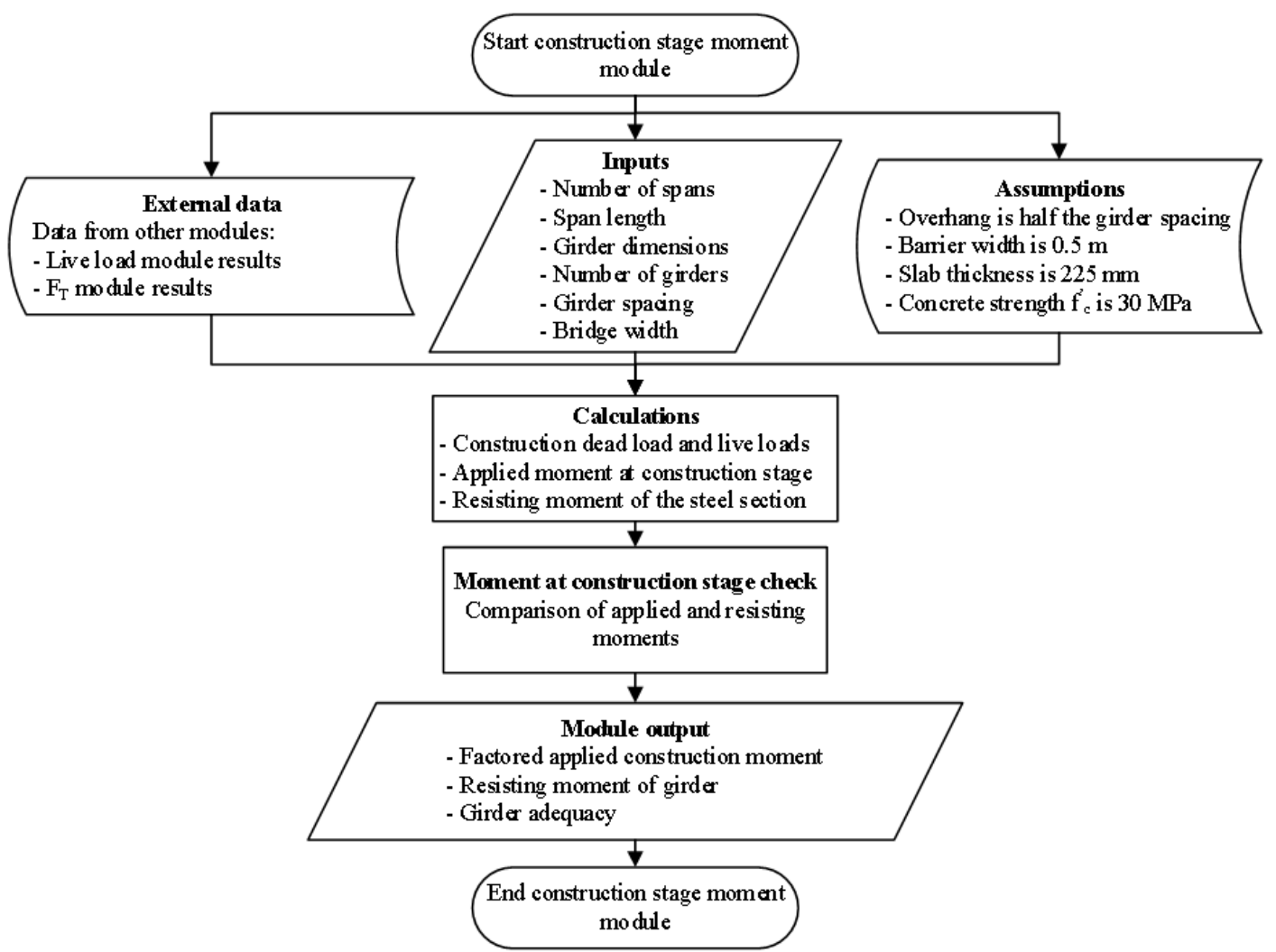

Figure 3: Flowchart showing the algorithm of girder ultimate moment resistance at the construction stage 


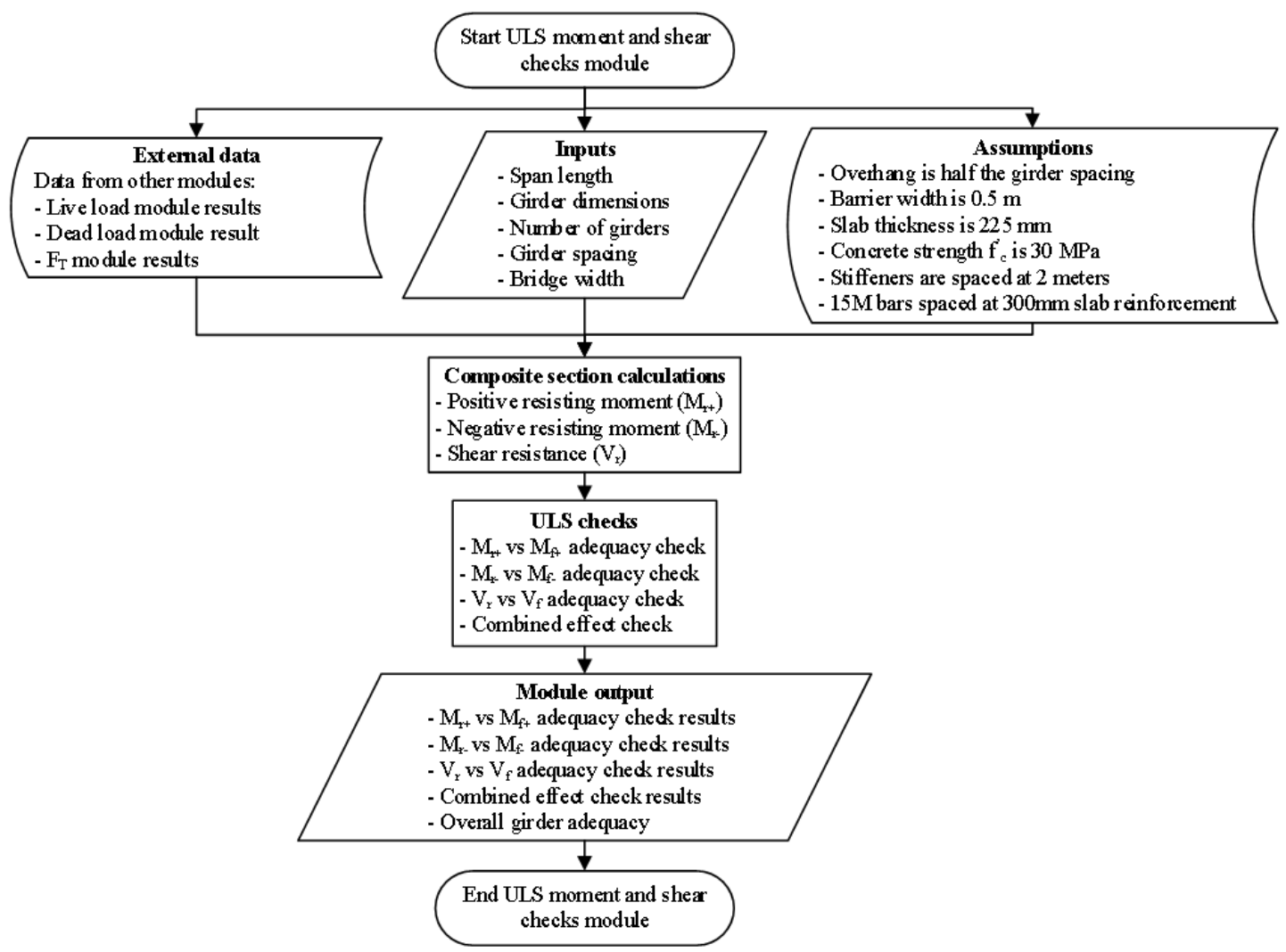

Figure 4: Flowchart showing the algorithm for the check for flexural and shear strength of the composite girder at ULS

\subsection{Algorithm for Check of Girder Flexural Strength at Fatigue Limit State}

Finally, this module checks for the fatigue limit state as per the CHBDC requirements. Using the data provided, this portion of the software calculates the number of fatigue cycles the bridge that is expected to sustain through its lifetime of 75 years. The software then uses that information to obtain the applied fatigue stress range and the resisting fatigue stress range and provide output regarding the selected girder section adequacy under these conditions. Figure 5 outlines the algorithm used to achieve this design check. 


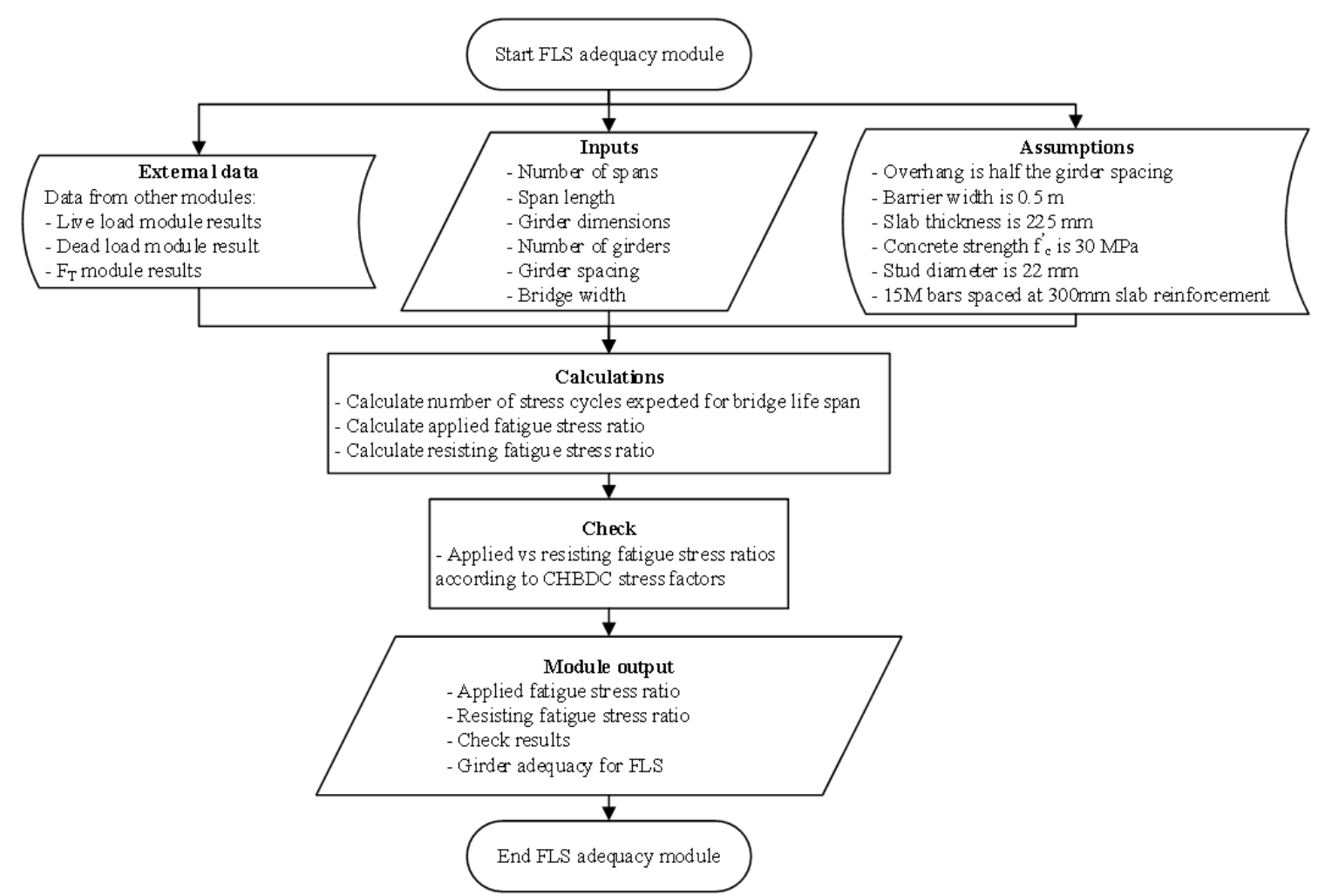

Figure 5: Flowchart showing the algorithm of composite girder adequacy for fatigue limit state

\subsection{Algorithm for the Optimization of the I-Girder Size}

All the previously mentioned algorithms were combined into an optimization module which runs the program in an iterative manner until the most economical girder size is found while meeting all limit state design criteria. As this portion of the program runs, it ensures a Class 2 steel section or a modified Class 3 section criteria per the provisions specified in Chapter 10 of CHBDC. Figure 6 outlines this portion of the software. 


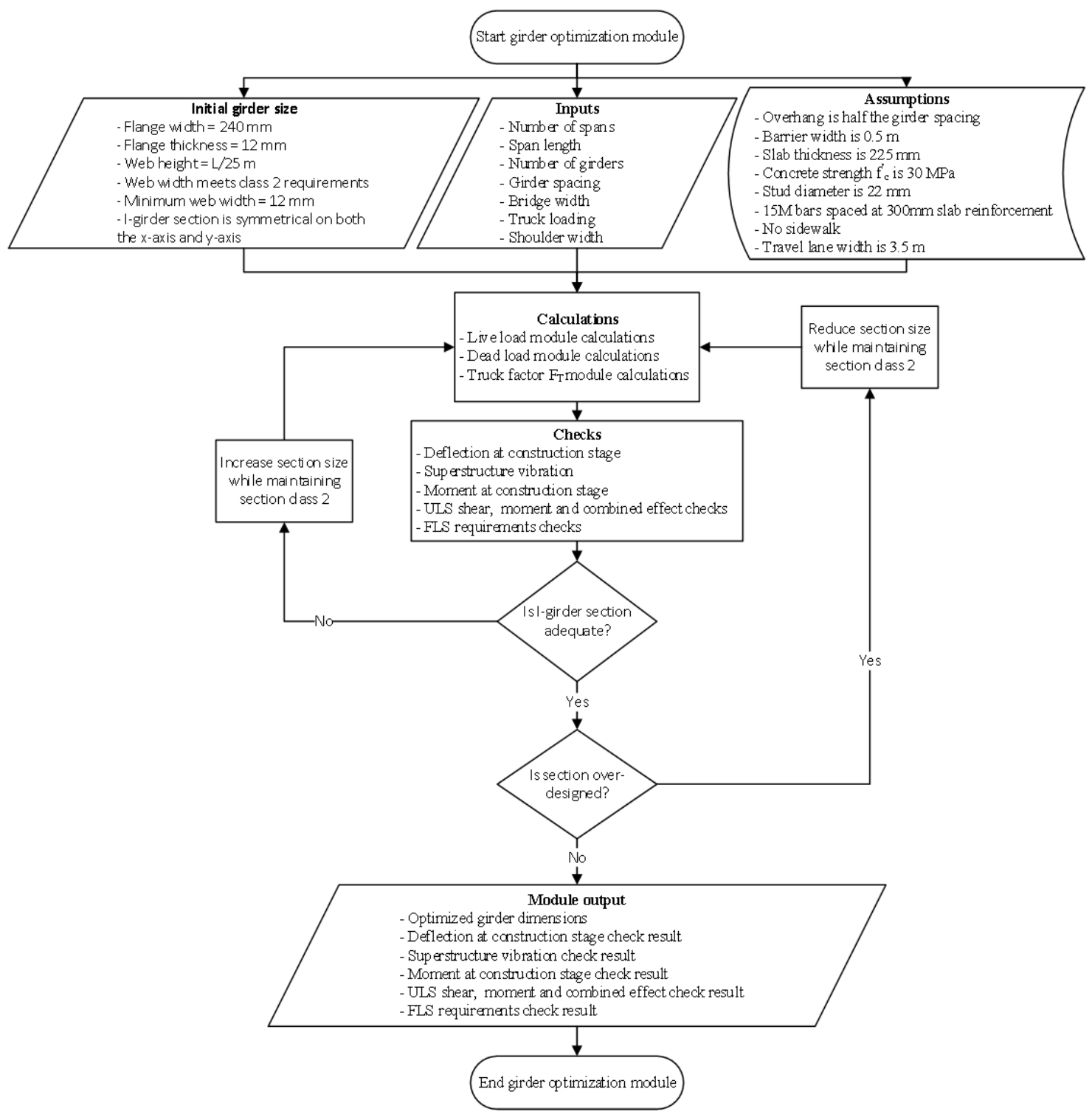

Figure 6: Flowchart showing the algorithm of the girder optimization module

\section{Program Overlay and Results Comparison.}

The screenshot of the program graphical interface can be seen in Figure 7 which outlines the software input and output locations. The CISC I-girder design example [8] was used to verify the program output as depicted in Table 1. As can be observed, the software provides accurate and conservative results when compared to manual calculations. The variation in some data is due to the assumptions made by the program. For instance, the shear resistance heavily depends on the intermediate stiffener spacing. The program assumes stiffener spacing at 2 meters. However, designers can choose to lower the spacing or increase it in order to match the applied factored shear at ULS. As for the remaining values, the program results show excellent representation of manual calculations with a slight overestimation of applied forces and underestimation of resisting forces. Other manual examples were also applied to the software and it showed similar results to the above table [8]. However, users of this software should be aware of the software boundaries as it is only designed to work under the following conditions: 1) bridges with a single span, two equal spans, three equal spans, and four equal spans; 2) span length between $12 \mathrm{~m}$ and $48 \mathrm{~m}$ and 3) CL-625 truck loading, CL625-ONT truck loading, and CL-800 truck loading. 


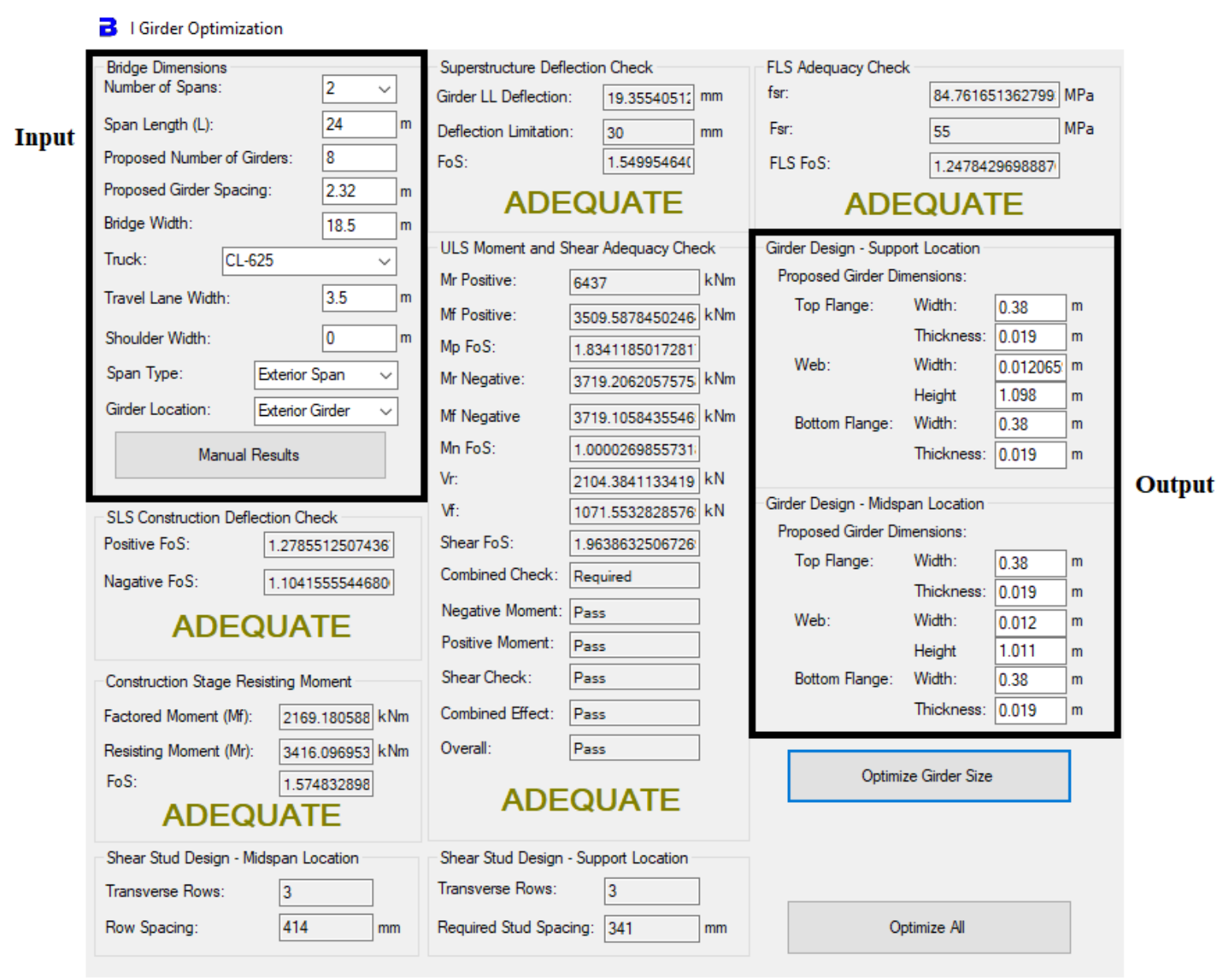

Figure 7: Screenshot of the graphical interface of the developed VB.Net program showing input and output parameters

Table 1: Result comparison between the CISC design example solution and software results

\begin{tabular}{|l|l|l|}
\hline Values & Manual results & Software results \\
\hline Factored applied moment, $\mathrm{M}_{\mathrm{f}}$, at ULS & $17,600 \mathrm{kN} \cdot \mathrm{m}$ & $18,200 \mathrm{kN} . \mathrm{m}$ \\
\hline Factored applied shear, $\mathrm{V}_{\mathrm{f}}$, at ULS & $1,739 \mathrm{kN}$ & $1,740 \mathrm{kN}$ \\
\hline Deflection limit, $\Delta_{\mathrm{Limit}}$ at SLS2 & $80 \mathrm{~mm}$ & $79 \mathrm{~mm}$ \\
\hline Live load deflection, $\Delta_{\mathrm{LL}}$, at $\mathrm{SLS} 2$ & $33 \mathrm{~mm}$ & $33 \mathrm{~mm}$ \\
\hline Factored applied moment, $\mathrm{M}_{\mathrm{f}}$, at construction phase & $10,000 \mathrm{kN} . \mathrm{m}$ & $10,200 \mathrm{kN} . \mathrm{m}$ \\
\hline Resisting moment of steel girder, $\mathrm{M}_{\mathrm{r}}$, at construction phase & $11,000 \mathrm{kN} \cdot \mathrm{m}$ & $11,300 \mathrm{kN} . \mathrm{m}$ \\
\hline Extreme fiber stress for SLS1 & $207 \mathrm{MPa}$ & $245 \mathrm{MPa}$ \\
\hline Resisting moment of the composite girder, $\mathrm{M}_{\mathrm{r}}$ & $25,000 \mathrm{kN} \cdot \mathrm{m}$ & $24,600 \mathrm{kN} . \mathrm{m}$ \\
\hline Resisting shear force of the composite girder, $\mathrm{V}_{\mathrm{r}}$ & $3,745 \mathrm{kN}$ & $3,250 \mathrm{kN}$ \\
\hline Shear studs at ULS & 3 per row @ $600 \mathrm{~mm}$ & 3 per row @ $600 \mathrm{~mm}$ \\
\hline Shear studs at FLS & 3 per row @ $430 \mathrm{~mm}$ & 3 per row @ $470 \mathrm{~mm}$ \\
\hline
\end{tabular}




\section{Discussion of Software Results}

By utilizing this software, additional research was conducted in order to determine macro patterns in steel girder crosssection sizes by optimizing over 6000 bridge configurations [8]. Some of the results of such macro analysis for single span bridges are presented in the following equations. The produced empirical equations representing the upper bound for the minimum required moment of inertia per unit width of the composite steel girder cross-section (Ics/S), moment of inertia per unit width of the steel girder cross-section (Is/S) and web area per unit width (Aw/S), irrespective of the number of design lanes, can be found below in equations 1, 2 and 3, respectively, for CL-625 truck loading. All of the equations presented in this paper are a function of the span length $(\mathrm{L})$ and girder spacing $(\mathrm{S})$ in meters.

$$
\text { Ics } / \mathrm{S}=25000\left(\mathrm{~L}^{2}\right)-720000(\mathrm{~L})+10^{7} \mathrm{~mm}^{4} / \mathrm{mm}
$$

Is $/ \mathrm{S}=12000\left(\mathrm{~L}^{2}\right)-360000(\mathrm{~L})+5 \times 10^{6} \mathrm{~mm}^{4} / \mathrm{mm}$

$\mathrm{Aw} / \mathrm{S}=(0.018-0.0029(\mathrm{~S}))\left(\mathrm{L}^{2}\right)+(0.022(\mathrm{~S})-0.19)(\mathrm{L})+5.85-0.91(\mathrm{~S}) \mathrm{mm}^{2} / \mathrm{mm}$

\section{Conclusions}

This research reported in this paper aimed at increasing the efficiency and optimization of structural steel design in the early stages of preliminary analysis for bidding purposes. By utilizing previously developed equations for applied moment shear and deflection due to single truck loading as well as CHBDC code requirements for limit state design, a VB.Net software was developed to perform analysis and design of steel and composite girders for all design limit states. The program is able to assess steel girder sections per CHBDC code requirements and produce an optimized steel girder section for the applied loading cases. Empirical equations were then developed for the minimum moment of inertia per unit width of the composite steel girder cross-section, moment of inertia per unit width of the steel girder cross-section and web area per unit width.

\section{Acknowledgements}

The authors would like to acknowledge the support of the Canadian Institute of Steel Construction to conduct this research.

\section{References}

[1] Prestressed Concrete Institute, PCI Design Handbook: Precast and Prestressed Concrete, Chicago, USA, 1978.

[2] Canadian Standards Association, Canadian Highway Bridge Design Code. Toronto, Ontario, 2019.

[3] N. Theodor and G. Al-Bazi, "Manual for Standard Short Span Steel Bridges." Ministry of Transportation Ontario, St. Catherines, Ontario, 1997.

[4] Ministry of Transportation Ontario, CANBAS GUI, Canadian Bridge Analysis System Graphical User Interface, User Guide, Downsview, Ontario, 2002.

[5] Ministry of Transportation Ontario, Ontario Highway Bridge Design Code, Toronto, Ontario, 1991.

[6] A. Diab and K. Sennah, "Simplified Equations for Moment and Shear Values in Bridge Girders Resulting from Truck Loading" in Proceedings of the Short and Medium Span Bridge Conference, Quebec, Canada, 2018, pp. 133-1 - 1339.

[7] Canadian Institute of Steel Construction, Steel Bridges Design, Fabrication, Construction Course Design Examples, Toronto, Canada, 2016.

[8] A. Diab, "Development of A Quick Design Method for Composite Concrete Slab-Over Steel I-Girder Bridges for Project Bidding", MASc Thesis, Department of Civil Engineering, Ryerson University, Toronto, Canada, 2018. 